\title{
The Grapes of Zeuxis: Representation in the Arts
}

RB: Erich Auerbach and Walter Benjamin were both born to assimilated Jewish families in Berlin in I 892. Both later studied literature at the German university, and after Hitler's rise to power both fled the country of their birth, Auerbach traveling to Istanbul and Benjamin to Paris. More importantly, during their exiles they both produced what are arguably the twentieth century's two most influential studies of representation in the arts: Auerbach's magisterial Mimesis, penned in Turkey and completed in I946, and Benjamin's brilliantly provocative "The Work of Art in the Age of Mechanical Reproduction," written in three versions between I935 and 1939. Are the connections between these critical essays merely coincidental, or do they run deeper, converging in significant ways on the aesthetic, the social and the political? Is it an accident that these works were produced by refugees from National Socialism and the mass propaganda it generated? Finally, are we justified in discovering parallels between mimesis in literature from Homer to Woolf and mimesis in photography and cinema? Indeed, might we extend the arguments of Auerbach and Benjamin to the simulacral culture of our own time-to mechanical reproduction as it exists on YouTube, Facebook and Twitter? Is the scar of Odysseus just another version of Paul Muni's and Al Pacino's Scarface, which itself anticipates the on-line fascination with Tina Fey's facial scar?

JS: Nietzsche observes that the ancient Greeks "were superficial out of profundity." I suppose, by contrast, that we moderns are, as you witheringly intimate, "profoundly superfacial." The

How to cite this book chapter:

Begam, R. and Soderholm, J. 20I 5. The Grapes of Zeuxis: Representation in the Arts. In: Begam, R. and Soderholm, J. Platonic Occasions: Dialogues on Literature, Art and Culture. Pp. 35-55. Stockholm: Stockholm University Press. DOI: http://dx.doi.org/IO.I6993/sup.baa.c. License: CC-BY-NC-ND. 
simulacra that variously divert us are three or four removes from Plato's Forms. But this is not the tack I want to take.

Our old friend and enemy, Jacques Lacan, thought the story about the two painters-Zeuxis and Parrhasius-showed that animals are compelled by appearances but human beings, with their oversized frontal lobes, are in love with secrets-the hidden, the mysterious, the veiled. It is one thing to fool the birds into descending with their bird-brains to peck fecklessly at painted grapes. It is quite another to paint a curtain so enticingly that one tries to pull it off the painting to reveal what it hides. Who was it-Frank Kermode?-who said that all great literature is based on a secret, on what the representation does not re-present, but makes at once pruriently and intellectually absent?

Yet another veiled illusion/allusion. I wonder if my reply to you, in the spirit of your inquiry, could take the form of reproduction/representation. And so my "re-ply" is my favorite piece of sculpture, which I recently admired in the Corcoran Gallery in Washington D.C. The marble veil and the face were of course chiseled simultaneously by the crafty artist. I am achingly intrigued by that simultaneity.

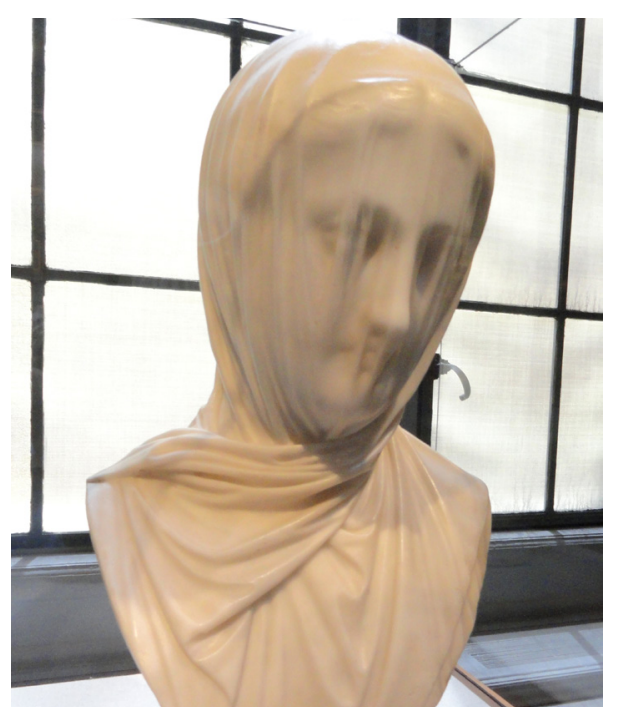

Figure 3: Guiseppe Croff, Veiled Nun. 
RB: Lacan has forgotten the Greeks-or confused them with animals. Auerbach argues that there are two styles of representation in the West: the Hellenic and the Hebraic. The former depends on an aesthetic of externality, on beautiful surfaces and seductive appearances, while the latter depends on an aesthetic of internality or transcendence, on depths that must be plumbed and heights that must be scaled. In Hellenic art, meaning and expression are effortlessly integrated-the one inhering in the other-but in Hebrew Scripture the reader labors to find the meaning below the expression, struggles to close the interpretive distance between surface and depth. Benjamin's program is different but related. For him the contrast is between the aura of traditional art and the mechanical reproduction of photography and cinema. With the advent of a xerographic technology, the ability of art to enchant or mystify-its auratic function-is destroyed. Before mechanical reproduction, the work of art is characterized by its uniqueness (there is only one Mona Lisa) and by its distance from the viewer (we must travel to view Leonardo's masterpiece). But once we can endlessly and effortlessly duplicate the Mona Lisa, the painting's uniqueness and distance are destroyed, with the result that we lose the quasicultic function of art.

Guiseppe Croff's sculpture, Veiled Nun (I 860), coyly illustrates Auerbach's and Benjamin's notions of art. We must pierce the veil, penetrate the surface, see into the depths of the sculpture in order to apprehend it properly. The veil stands for a kind of interpretive resistance that prevents us from moving beyond appearance to essence. In chapter two of The Genesis of Secrecy, Kermode writes "If we want to think about narratives that mean more and other than they seem to say" then we should consider the "parable." Croff's sculpture presents a parable that is a paradox: the veil renders the secret visible, draws our eyes to the unseen, detains us in the fold (as did your re-ply) that deliciously joins surface and depth.

JS: I think part of what so intrigues me about Veiled Nun is the lack of resistance that allows us to see at once the face beneath the veil and the veil itself. It is a paradox or a kind of phenomenological conundrum. Add to the mystery the fact that 
a face, too, can be a veil, especially a nun's face, which may serve both to reveal and veil a woman's interiority, her spirituality and her sexuality. But, to me, there is something hermeneutically suggestive about that sculpture and its transparent secret. Pondering both gaps in clothing (slit skirts that reveal, suddenly, a flash of flesh) and gaps in texts (moments where the reader is invited to author meaning), Roland Barthes wrote: "Is not there the most erotic place-there, where the garment leaves gaps?" One also recalls the lasciviously gap-toothed Wife of Bath and her radically "heterotextual" "Preface," which-busy with quotations from authoritative texts-both reveals and hides (adds a layer of skin, or a skein) to the Wife's intention to find Husband Six on her way to Canterbury. No veiled nun, the Wife, but one can still get lost in her "folded" sexuality/textuality.

I wonder which is the more "advanced hermeneutics"- the Hellenic or the Hebraic? Does not Auerbach plump for the former? Does not Veiled Nun somehow combine or fuse the two kinds of interpretation, or perhaps even short-circuit them precisely because its distinctive, magical aura turns depth into surface, surface into depth, in a single moment, at first glance and at last gaze?

RB: For Auerbach, the Greek text is transparent, the Jewish text opaque. Does he prefer Olympian cloudlessness or Mosaic abstraction? The epistemology of the surface or the hermeneutics of depth? Critics tend to incline to the latter, though one suspects that Auerbach's categories are more dialectical than oppositional. Certainly the great essays in Mimesis- "Odysseus' Scar," "The World in Pantagruel's Mouth," "The Weary Prince," "The Brown Stocking"-organize themselves around an interplay of surface and depth, and it is that interplay that Veiled Nun so beautifully illustrates. Insofar as we see through the veil, it is transparent, but insofar as we see the veil itself, it is opaque. It is a kind of membrane (one thinks of Derrida's “Tympan") that mediates between, while joining together, outside and inside. Or if you prefer, it is a version of Kermode's "parable” (from the Greek parabolē), which carries suggestions of "comparison," "illustration," "analogy." "Like" but not "is," the parable occupies that ambiguous space "between," the Barthesian gap of interpretive play. 
In Book XIX of The Odyssey, Euryclea recognizes Odysseus by his scar-she "reads" the surface-and yet the scar itself has "deeper" significance. It is at once the sign of his rite of passage to manhood (symbolically wounded in the thigh, he nevertheless kills the boar) and also a portent of his future success (he will vanquish the suitors and reclaim his throne). The scar looks backward and forward in time. It is confined to a fold of skin, but beneath it lies a complex, temporal archaeology, a narrative chain of interlocking analepses and prolepses.

Similarly Croff's veil-a curtain of air and a sheet of marbleseamlessly flutters in its polysemy. At one level, the veil is simply itself, not a sign but a surface, a garment worn by a nun, the literal expression of her "having taken the veil." And yet, as a moment's reflection shows, this cannot be the case. Nuns wear wimples not veils and, whatever their head-covering, they never show their hair. Might the veil of this well-coiffured woman be a sign for something else? Notice that as the fabric falls to the woman's neck, it tightly winds around her throat, enclosing, grasping, strangling. Is Croff offering his commentary on the fate of the young woman, drawing an analogy between the veil and the noose? Indeed, pushing matters further, might we say that this is not a veil at all, but a shroud? Notice her lifeless eyes, the forward-drooping head, the preternaturally peaceful expression of her face. Perhaps Croff is suggesting that having taken her vows, she is now dead to the world. But let us slip deeper into the folds of this hermeneutic unravelling. Might the delicate membrane that covers her face be meant to remind us of another membrane-one that will forever remain intact, unpenetrated, inviolate? Croff has sculpted both the death of love (she is buried alive) and the love of death (the essence of Christianity). It is at once a parable itself and a parable about parables (all those veiled allusions).

But here I think it is worth pausing to remind ourselves of a simple fact. What you and I have been talking about is not Veiled $\mathrm{Nun}$, which is a life-sized bust housed in the Corcoran Gallery, but a two-dimensional image, approximately $2^{1 / \frac{2}{2}}$ inches by 3 inches, which exists in hyperspace. My question: have we been discussing Croff's sculpture at all? And if not, what is the relation between the mechanically produced image you imported into this dialo- 
gue and that sensuously arresting piece of marble in Washington, D.C.?

JS: The bad news: the "pixilated" Veiled Nun has no aura at all once she is torn from her gallery setting and wanting her third dimension. The good news: I can look at her whenever I fancy, which is often. Indeed, I can now stroll through most of the major art galleries and museums in the world whilst sitting at home and staring at my computer. I cannot think that is necessarily a degrading, degraded activity, despite my not being radiated by or bathed in the sensuous, ritual aura of the original work of art.

Even a mechanical reproduction of Veiled Nun gives me a certain frisson. I imagine Croff, chisel in hand, working in the least diaphanous of materials (marble) and banging out both a lovely face and a lovelier veil with the same stroke of the small hammer. The illusion produced is one of the most enchanting and engrossing I have ever come across. It trumps every trompe l'oeil I know-and I've known quite a few.

RB: Your pragmatic response (mechanical reproduction has its advantages and disadvantages) makes perfectly good sense, but I suspect that philosophers like Benjamin and Heidegger would claim that it ignores a larger aesthetic question. For them, the work of art fundamentally changes-is transformed in its essential being-when it becomes a simulacrum. For Benjamin, those changes are potentially liberating: the function of art shifts from "ritual" to "politics," with all that promises (from Benjamin's perspective) for social progress. For Heidegger, those changes are profoundly destructive: the work of art in losing its origin loses its ability to open itself to truth. In both cases, mechanical reproduction fundamentally alters the ontological status of the work of art.

To speak in Heideggerian terms, when the veil is no longer palpable or present, when the Greek temple loses its cultic function, it ceases to be a Greek temple. Veil-less, it is unable to draw us into the "unveiledness" of alètheia. The work of art becomes a piece of archaeology, a ruin of its former self, a simulacrum of what it was. 
JS: It's not the ontology of Veiled Nun that appeals to me, or the lack thereof because she is missing one dimension. Even as a reproduction, the piece's astonishing craftsmanship and splendid illusion comes through every time. Do I prefer visiting her-my sacred, marbled mistress-in Washington, D.C.? Yes, of course, but her "presence" on my computer screen is not hugely diminished because she is merely an image. As for Heidegger, I don't think his ontology has much to do with certain aesthetic responses that are both supple and subtle, as you have so ably demonstrated above in your writing about a work of art you have seen on your computer screen. In this particular case (I am a case-by-case man) Veiled Nun really does it for me "in person" or in reproduction.

Now, the Parthenon rebuilt in concrete in Centennial Park in Nashville, Tennessee-that, my friend, is another case altogether. Behold this aura-less travesty of a mockery of a sham.

RB: Given our discussion of Veiled Nun, I would have thought Heidegger's "truth-as-unveiling” would flutter your imagination a

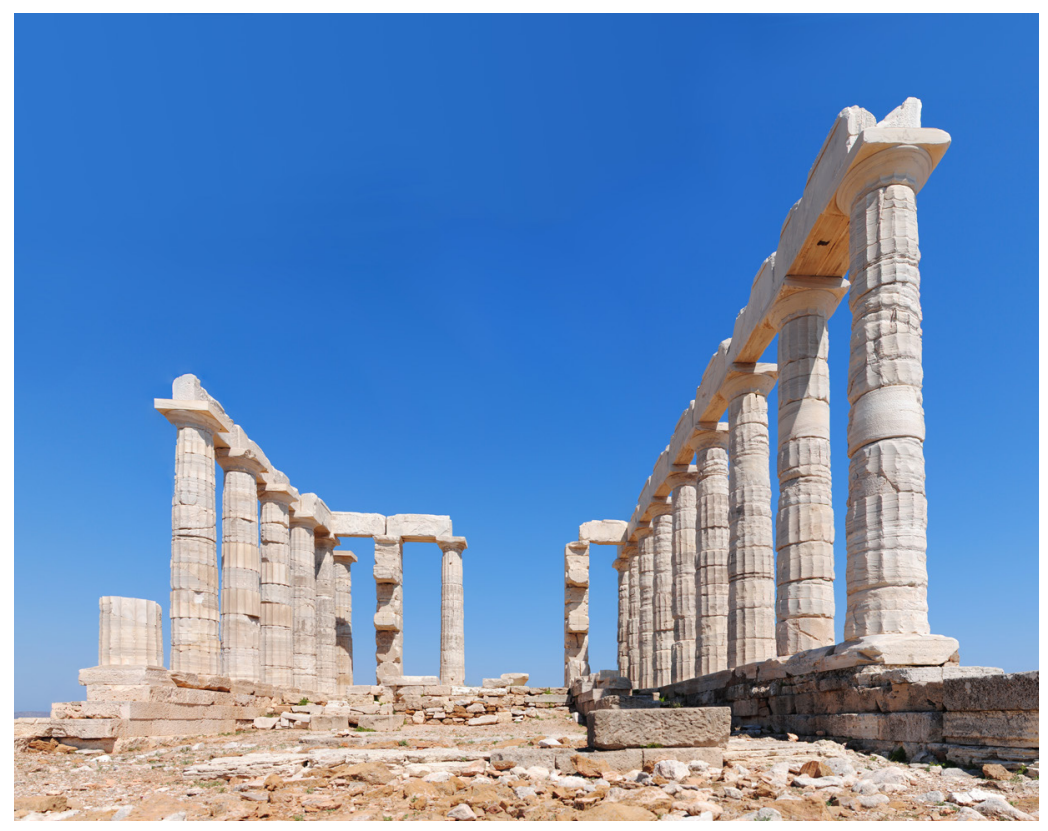

Figure 4: Temple of Poseidon. 
bit more. If not, let me pass on to the Nashville Parthenon and ask a simple question: assuming that it is a structurally exact reproduction of the original, would your opinion of it be different if it had been executed in marble rather than concrete? In other words, taking it as a perfect replica (marble and all), wouldn't your local version of the Temple of Athena be just as good as the one on the Acropolis? Indeed, wouldn't it be even better, because you would have it, so to speak, in your backyard?

JS: Materials matter. There is something obscene and kitschy about a concrete Parthenon. And the damned thing is already decaying after just over one-hundred years. I called your attention to the Nashville Parthenon precisely because it is so devoid of its ritualistic aura in its Dixie setting. Having said that, imagine all those bus-loads of school-kids who will never see the original on the Acropolis. Perhaps a few of them will be enlivened by Greek art and culture because of their tramping through the concrete Parthenon (they don't care that it's not marble). It is also not reduced to ruins (yet), but a perfect scale model that gives you

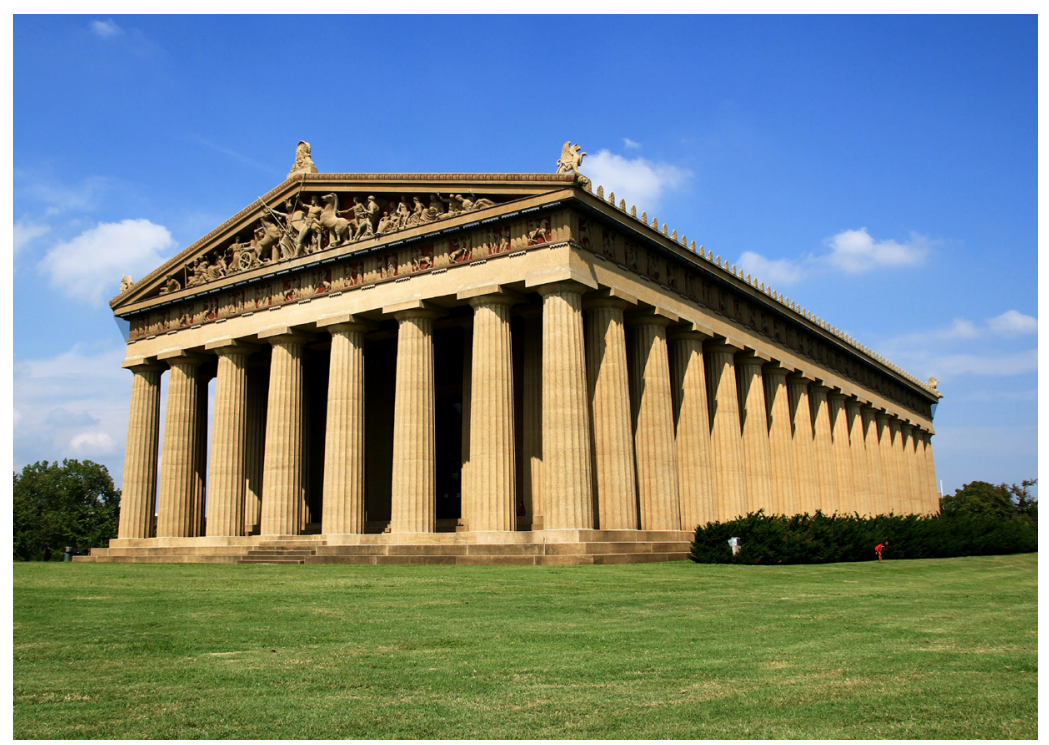

Figure 5: Nashville Parthenon. (Mayur Phadtare, 2012. Creative Commons License) 
a far better sense of the lovely symmetry and graceful proportions of the original. What's astonishing is that the good citizens of Nashville would ever have constructed their "Parthenon" in the first place-and over a century ago, when the South was, one imagines, far less culturally-astute than it is now.

RB: And the answer to my question is ...?

JS: I prefer certain reproductions to others, case by case. I have no purchase on the precious "aura" of most works of art anyway, so why pretend otherwise?

RB: Yes, case by case. And the case before us is the Nashville Parthenon. Would you object to it if were an exact replica, if it were identical in form and material to the original?

JS: If reading T. S. Eliot has taught me anything, it's that modern life-even one hundred years ago, but probably even 2000 years ago-is miserably demythologized and de-ritualized for most people crawling from womb to tomb. That goes for any viewing of any Parthenon, the one in Athens or the one in Nashville. To amend Heidegger: "we are too late for ritual, too early for Being." Even if you put the handsomely, "romantically" ruined Parthenon, marbly piece by piece, in Nashville, I would not be "aura-struck" by it. Let us remember our Wittgenstein: To imagine [the language] of ritual is to imagine "a form of life." And I am necessarily utterly divorced from any form of life that would make the Parthenon glow or radiate its magic. By the way, the same divorce holds for my appreciation of Canterbury Cathedral, which I can see from my desk at this very moment. Have I finally answered your question, Dr. Benjamin?

RB: Pragmatist that I am, I too have no use for the cultic function of art, whether it involves radiating auras à la Benjamin or "worlding worlds" à la Heidegger-though it is worth remembering that Benjamin himself was of Brecht's party and therefore celebrated the triumph of an aura-less "political" art over an aura-packed "traditional" art. I pressed you on the question of the 
Nashville Parthenon because it seems to me that at a minimum art, as opposed to craft, does require a fully individualized source or point of origin. If I make a copy of the Mona Lisa, I haven't produced a work of art but a forgery. Of course, in our contemporary "down-load" culture, there is no such thing as origin or originality or copy: it's simulacra all the way down.

But there are real-world consequences to the aesthetic of the simulacrum. Our relation to the work of art is profoundly altered. It is not simply that the "work" of art loses its "workly" status, the sense that it is the product of an act of labor, which required time, thought, energy, design, talent, craftsmanship and perhaps even a little genius. The reception of the work of art is also profoundly altered. When Ruskin communed with the Italian masters, he didn't peruse a book of reproductions, surf the Internet or take a virtual tour of the Doge's Palace. He literally trod the stones of Venice. And rather than "capture" on his iPhone the paintings and architecture he saw, he painstakingly entered detailed sketches of these wonders into his portfolio. His relation to the art he described was fundamentally-indeed ontologically-different from our relation to art in the Age of Mechanical Reproduction.

JS: Like Adam, I am tempted to accept and fatally munch on your apple from the Tree of the Knowledge of Authenticity and Reproduction, especially since in my well-wrought, diurnal rounds, I pass by Walter Pater's "wave after wave of stone" called Canterbury Cathedral and "get" almost nothing out of it, as I mentioned a few exchanges ago. My benumbed students cannot tell me-I perversely ask them every two weeks-how many towers the Cathedral has in total. The Cathedral is, like Latin, a dead language, hardly aesthetically compelling or, indeed, perceptible, for most of the dead pilgrims that obligingly, during sweet or cruel April, sojourn here to wander through it. The very possibility of ritual has degenerated into deadening routine, which is also largely the point of The Waste Land. So perhaps I am even more hideously grim than you are on this point because, just strolling to work, I witness tourists by the thousands treating The Real Thing as a Reproduction even as they pretend to adore it. 
And yet I have to wonder (and make you wonder) how far Art has ever been sensuously entangled with ritual and myth. For every ancient Athenian who made the pilgrimage up the steps to the Acropolis to moon over Athena Parthenos, there must have been thousands who did not want the Parthenon to happen, who just walked dully along, looking for a good ouzo fix and scratching their innocent Greek arses on the nearest olive tree.

RB: Your rounds may be diurnal but I don't for a moment believe that a slumber has sealed your aesthetic spirit. Indeed you and I have, of a summer's day, lingered on the vast lawn that joins The King's School with the Cathedral, transported by that gravity-defying, heaven-ascending behemoth, delighting in its every line, lineament and volume. There may not be a God, but anyone who has really seen the Cathedral will understand why men once believed in Him.

Has art always been the purview of the privileged few? Certainly aesthetic souls have been complaining about philistine indifference since antiquity, as Petronius's Satyricon so memorably illustrates. Nevertheless, I think Benjamin is correct when he argues that with the advent of mechanical reproduction "the total function of art is revolutionized." This revolution has extended itself most profoundly and pervasively in our time as a form of simulacral culture. When everything becomes digitalized, virtualized, plugged in, it is no surprise that your students no longer apprehend the Cathedral, let alone the civilization that produced it.

Of course, there's nothing new or interesting in whinging over the fact that we've all gone digital. After all, I'm sitting at my own computer right now, as you may be at yours. What does interest me-and perhaps is worth thinking about-is how modernism may have contributed to the general degradation of aesthetic perception in our own time. I'm rather fond of Marcel Duchamp's famous I9I7 "ready-made," Fountain. By signing it R. Mutt (with its pun on the German Armut or "poverty"), he reminds us that a poor man's fountain (not to mention art) will be decidedly less elegant than a rich man's. Duchamp has added just enough to his readymade-and its deconstruction of Kantian anti-utilitarianism-to make it a witty commentary on the materiality and function of art. 
Having said that, I was nevertheless amused to discover the image shown below, which the "curators" of Google Images scrupulously inform us is a reproduction not of Duchamp's I9I7 “original" but of a I950 "replica." No doubt there is a substantial difference in monetary value between the two objects. But is there any difference in aesthetic value? Indeed, does it make sense to distinguish between originals and replicas when talking about Fountain? For that matter, would it be possible to make a "forgery" of Duchamp's sculpture? Presumably it would be a "replica" masquerading as an "original," though of course the whole point behind a ready-made is there is no original. Which leads me to a question: Once it's simulacra all the way down, is there any way back up-back up to those towers your students can no longer see?

JS: Did you know that beer-swollen tourists regularly peeor try to pee-in Fountain? Well, they do, according to museum employees. That it is impossible to pee-or try to pee-in or on

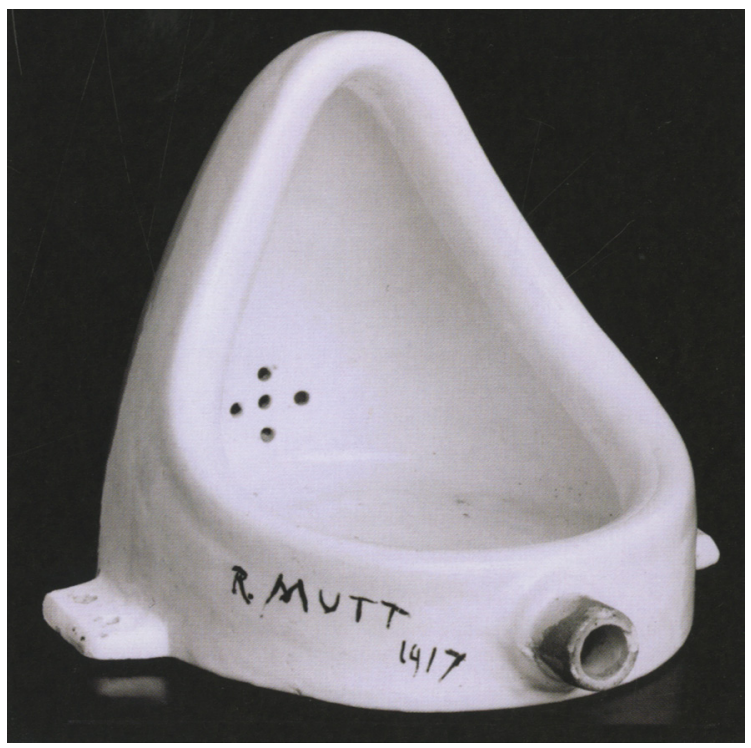

Figure 6: Marcel Duchamp, Fountain (replica). (๔ 2014 Succession Marcel Duchamp) 
Veiled Nun must say something about what has happened to "Art" in the modern world. For hoi polloi, the "original" is so mimetically compelling that one might as well empty one's bladder in it. Or is Art so tedious and jejune that one can treat it as the chance to void one's wasteland of Miller Lite? Are we Paterians the judge of anything once the idea of judgment, both artistically and critically, has become shit-or once the veil has been torn and shredded?

RB: Zeuxis' birds peck and Duchamp's tourists pee. In both cases, viewers respond to what we might call the mimetic imperative, except in the case of Fountain the work of art is not an imitation but the thing itself. Or is it? Arthur Danto would say once Duchamp's ready-made enters the museum it has become art.

JS: I categorically reject Danto's formulation and the whole "institutional" definition of art. That's how Tracey Emin was anointed-by the pretentious Saatchi.

RB: One may disagree with Arthur Danto's "The Artworld" but one must give reasons. You begin to sound like Testadura, Danto's version of the philistine in the museum.

I might point out that the principal artist Danto is defending in his classic I964 essay is not Tracey Emin, or one of the other Saatchi artists, but Andy Warhol. Here is Warhol's 1962 Electric Chair: mechanical reproduction meets mechanical destruction. Care to comment?

JS: I shan't defend Warhol. I cannot imagine one of his works that makes me think or feel profoundly. "Pop art" is, for me, an oxymoron that appeals only to lovers of mass culture, camouflaged as chic art critics. You are clearly not among them. Art, as I understand it, dies miserably in that electric chair. The electricity is a kind of didacticism, all the more shocking for being slyly but finally insufficiently ironic. If we want to ponder Veiled Nun's evil twin/s, how about Warhol's “Marilyn” series?

RB: I think Warhol is one of the major artists of the second half of the twentieth century. He is to the America of the I96os 


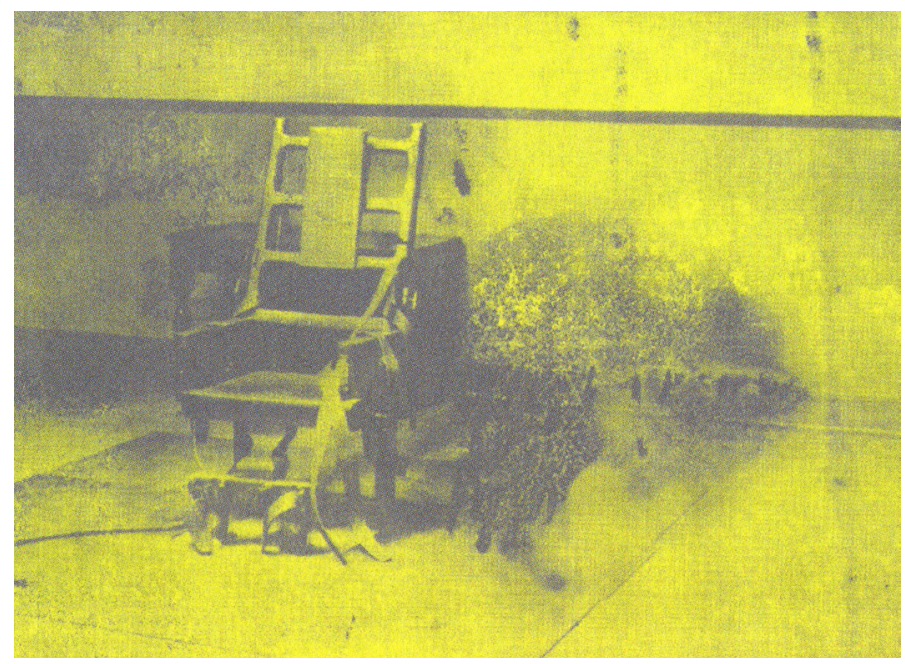

Figure 7: Andy Warhol, Electric Chair. ( 2014 The Andy Warhol Foundation for the Visual Arts)
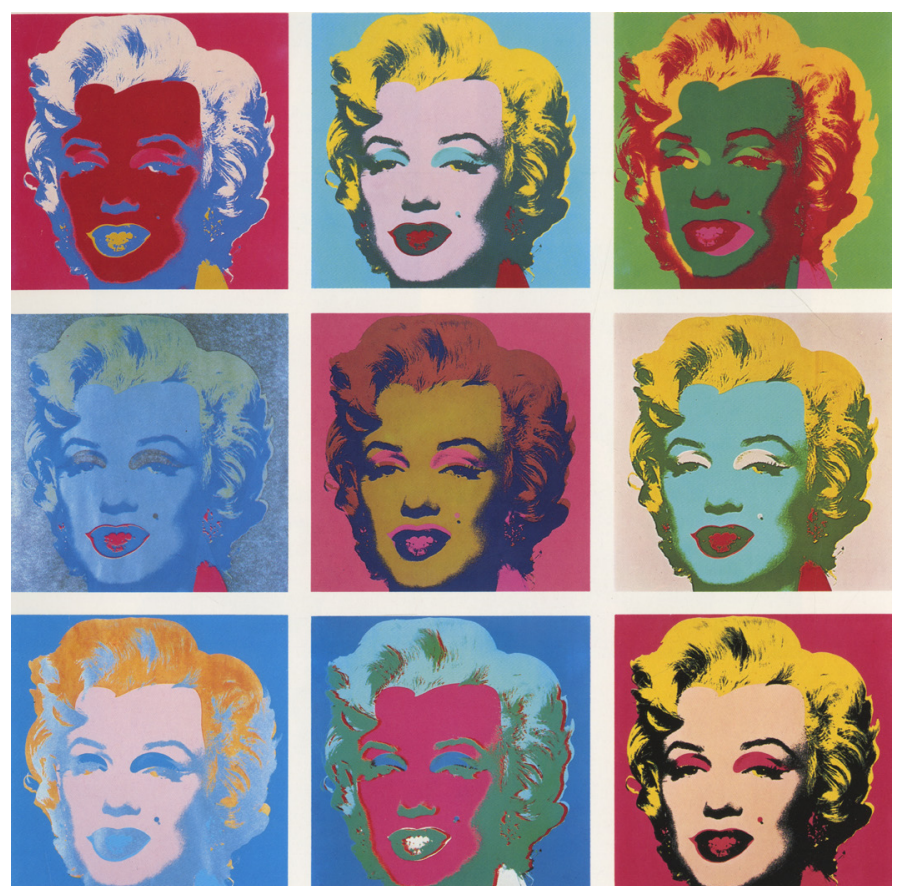

Figure 8: Andy Warhol, Marilyn Monroe. (๔ 2014 The Andy Warhol Foundation for the Visual Arts) 
and 70 s what Flaubert was to France of the I 848 Revolution, the Second Republic and the Second Empire. Both men constructed their art out of the popular culture of their time. In the case of Flaubert, it was sentimental novels, political journalism and the "democratization" of knowledge, as represented by the nineteenth century's reimagining of L'Encyclopédie. In the case of Warhol, the bill of particulars is familiar-from Hollywood to Madison Avenue to Celebrity Culture. Part of Warhol's brilliance consists in his having been the first artist (and this in the face Clement Greenberg's strictures on modernism) not merely to abandon abstract expressionism but to glory in the naïve imagery of mechanical reproduction. Of course, Warhol ironically distances himself from that reproduction-indeed introduces into it a commentary that savagely skewers the culture of xerography, even as it documents the ways in which celebrity has replaced aura.

Veiled Nun is lovely and provocative. But a hundred years from now everyone will know who Andy Warhol is, while today virtually no one knows who Guiseppe Croff is. And that's because his sculpture is a highly accomplished but largely derivative example of the academic style of the period. He is, in a word, a talented and gifted craftsman, who nevertheless failed to create original art.

But this is not to say that Warhol provides aid and comfort to the champions of simulacral culture. You call him a "Pop" artist, but that is a term more accurately applied to someone like Peter Max, who sold massively in the I960s and 70s precisely because he valorized the most vapid clichés of his time.

No one in Warhol's America wanted to be told that their country was a collection of mass-produced Campbell soup cans, blood-splattered Jackies, or ghoulish electric chairs, but the youth culture of the period took it as a matter of faith that psychedelic love would transform the world into utopia. Max's immensely successful "Love" poster-which sold thousands-delivered precisely that feel-good message. It was the Pietà of the period, bringing a cannabis-laced aura to every dorm-room in America.

JS: I don't like the way Warhol has it both ways: sneering at vulgarity and laughing all the way to the bank as he mass- 
produces that vulgarity. Flaubert's lyricizing of vulgarity is memorable because he spent five years writing Madame Bovary, often working ten to twelve hours per day. Surely Warhol's manipulation of his vulgar idiom will have no lasting appeal. It is the creature of fashion and caprice, willfully so. I agree that Veiled Nun is aca-demic and derivative. But it is not a collection of soup cans that one can look at for two seconds, get the joke, and then glide away on museum-legs to pretend to care about the next travesty of art.

RB: Is the test of aesthetic value how much time the artist put in? Dr. Johnson could rip off a Rambler faster than most caffeine-crazed bloggers can construct a paragraph. Mozart composed symphonies in half the time the average rock musician spends writing a song. Voltaire, Goethe, Dickens, Picasso, Stravinsky and Pound all created with amazing rapidity and dexterity. But this is irrelevant. Surely we judge art on the results, not how quickly or slowly it was produced?

I have no idea whether Warhol laughed, cried, smirked or smiled on the way to the bank, and I don't much care. Though I am pleased he was well paid for his art, which is rarely the case. You say that Warhol will have "no lasting appeal," but we are now some twenty-five years out from his death, and his reputation continues to rise. Certainly his work is not merely a "creature of fashion," since the fashions he was critiquing are long forgotten. One need only turn to Peter Max to see how out-of-date a real "creature of fashion" looks today.

Is Warhol an artist of the first order? Probably not. But for my money he is an important artist of the second order, which is no mean accomplishment, and I would bet he will still be hanging in museums fifty years hence-if we still have museums. And it is to that last point that I would like to turn. We have discussed how representation has moved from a Hellenic celebration of the surface to a Hebraic plumbing of the depths, from mechanical reproduction to digitalized simulacra, and I have asked several times if the technological revolution Benjamin identified has fundamentally changed our idea of art. I still remain unclear as to your response. 
For me, the status of art has been profoundly transformed in our time, not entirely as a result of mechanical reproduction (and the simulacral culture that followed) but significantly aided and abetted by these changes. That transformation consists quite simply in contemporary culture having eroded-perhaps having eliminated-the distinction between art and entertainment. The former requires culture, education, time and taste, while the latter is instantly and effortlessly available to all. The former participates in tradition, while the latter is an expression of fashion. The former speaks to all times, while the latter speaks to one time and that an increasingly brief time (Warhol's "fifteen minutes"). The scar of Tina Fey will be forgotten tomorrow. The scar of Odysseus will last forever.

JS: Twenty-five years is not much. Dr. Johnson recommended one hundred years. I think that's about right because it means the work has survived caprice and fashion and has remained compelling. I don't at all disagree with your main point about how mechanical reproduction has vitiated art. Indeed, I maintain that is precisely what the "achievement" of Warhol demonstrates. I will never get my head or my heart around an artist who said, as Warhol did, “There's nothing so American as shopping and I am an American.” And I am not in the least persuaded-although I steadfastly refuse to do the necessary "research"-that rock musicians labor over their compositions longer than Mozart did when he wrote, for example, Symphony No. 25. You must know of some profoundly assiduous rock musicians. I do not. I think of Warhol as important for showing just how far art has dropped into disrepute. If that was his point, then good for him. But it's a dead end.

I will get myself to a veiled nunnery and delight again and again (and again) in how Croff magically sculpted a veil and the face beneath at one go. That illusion of surface and depth continually enchants, even mesmerizes.

RB: My point regarding Mozart and Samuel Johnson was simply that the speed with which they composed tells us nothing about the quality of their art. You declined once again to take up 
the question of Benjamin and mechanical reproduction. Any final thoughts?

JS: Benjamin was prescient, no doubt, in his thinking. Pretty soon we will all be so "translated" into our computers and so obsessed with reproducing and digitizing ourselves and everything around us that we will utterly lack the sensitivity and moral intelligence to respond properly to the scar of Odysseus.

RB: Of course, Benjamin welcomed the Brave New World of mechanical reproduction. For him, better political engagement than cultic mystification, better Muni's Scarface than Odysseus' scar. From our present vantage, Benjamin's belief in the cinema as an extended exercise in Brechtian Verfremdung seems wildly naïve-a point Adorno himself made in a 1936 letter to Benjamin.

Then again, photography and the cinema are fully legitimate art forms that have now produced their own rich and varied histories. And lest we forget, movable type is itself a form of mechanical reproduction. Should we, perhaps, apply some Brechtian Verfremdung to ourselves? In The Wizard of $\mathrm{O} z$, the "man behind the curtain" is a symbol for Hollywood itself-all those spectacular effects are revealed to be nothing more than the by-product of techne. . But isn't Croff's "woman behind the veil" herself the by-product of technee? Indeed, hasn't the illusion-making of art always depended on the craftsman's ability to use his tools to good effect? "Et ignotas animum dimittit artes" ("and he turned his mind to the obscure arts") Ovid says of Daedalus, and Joyce says of Stephen. Perhaps it is the labyrinth that most perfectly illustrates the interplay of Auerbachian surface and depth? Perhaps art has always feared becoming entrapped in its own technologies? But what's an artist to do? The wings he would use to escape are as much the product of techne as the labyrinth from which he seeks to escape.

JS: I respond to art precisely because it does not have a silly dog pulling aside its curtain-or veil. Croff chiseled both woman and curtain simultaneously. That form of techne, that sensitively, sensuously-tooled illusion, seems to me a felicitous acceptance of 
the artist's “croffmanship." Even labored puns—as you can seelove to take the veil, presenting two levels or layers at once. When Toto (the currish cynic) pulls aside the curtain to reveal the frantic Wizard, puffing and bellowing and wildly gesticulating, I lose all interest in $\mathrm{Oz}$. Too much infrastructure.

RB: You have returned us to one of the unanswered questions with which I began, so let me re-ask it as we head toward a conclusion. Auerbach and Benjamin, both refugees from National Socialism, fled a culture dominated by the manipulation of beautifully deceptive and deceptively beautiful images. Albert Speer and Leni Riefenstahl were Hitler's Überwizards, and the Oz-like spectacles that they contrived had the effect of turning the Third Reich into a huge Gesamtkunstwerk. To what extent are Auerbach and Benjamin products of their own history, critics who seek to sensitize us to the lures of mystification, whether it is generated by seductive surfaces or cultic auras? Are they, like that other cynic, Bertolt Brecht, of Toto's party, employing alienation-effects to remind us that the man behind curtain-or maniac behind the veil-is simply pulling the strings on which we dance? Albert

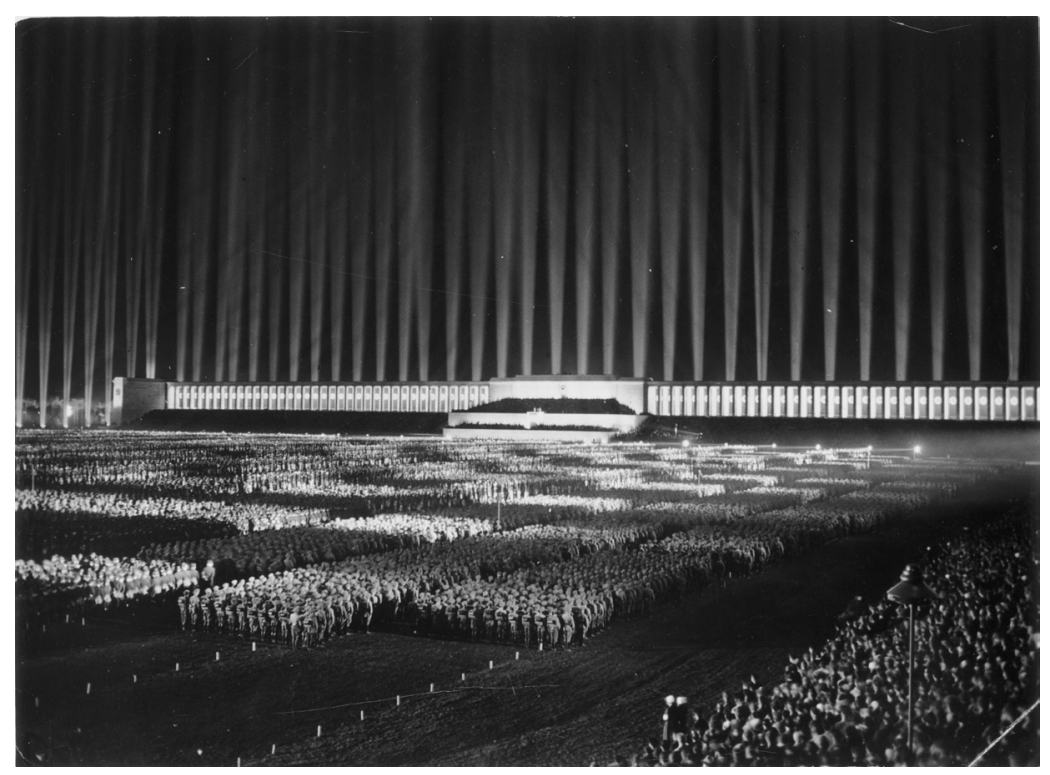

Figure 9: Albert Speer, Lichtdom. 
Speer's "Cathedral of Light" from a I930s Nuremberg rally was described by the then British Ambassador, Sir Nevile Henderson, as "both solemn and beautiful ... like being in a cathedral of ice." Where do we place it in relation to the Parthenon and Canterbury Cathedral, each of which, in their different ways, helped inspire it? And is it a "sensuously-tooled illusion" that we should sustain or destroy? Should we treat it as an icon, or should we treat it iconoclastically?

JS: Do we have any record of what Benjamin thought of Riefenstahl's Triumph of the Will (I935)? Is his famous essay of I936 a cautionary meditation on the dangers of manufacturing aura, ritual and tradition for the beleaguered, hopeless masses? I think Benjamin must have loathed Riefenstahl's work as a perversion of his hope that art could revolutionize the masses away from fascism and toward communism.

We must recall Benjamin's famous last words in "The Work of Art in the Age of Mechanical Reproduction": "Mankind, which in Homer's time was an object of contemplation for the Olympian gods, now is one for itself. Its self-alienation has reached such a degree that it can experience its own destruction as an aesthetic pleasure of the first order. This is the situation of politics which Fascism is rendering aesthetic. Communism responds by politicizing art." But do we know precisely what Benjamin thought of Riefenstahl's work? Did he attack her in print before he died in I940?

Finally, speaking of self-alienation and film, I sometimes wonder if our mass obsession with films about destruction (from cars blow-ing up to White Houses and Death Stars exploding) is contemporary culture's way of aestheticizing its death-instinct. Thanatos is so compellingly cinematic. We look down on our own calamitous destruction as if we were wistful Olympian gods, rather than part of the smoking, radioactive rubble: self-alienation copulating with self-delusion of the first order. To contemplate, through film, the ever-burgeoning nuclear "mushroom cloud" (two metaphors! - at once distancing and making familiar) is simultaneously to marvel at our godlike powers of creation and destruction and to drag back the curtain on our lethal wizardry. 
This is what happens when we allow cinema to put a film over our eyes.

The closing sequence from Dr. Strangelove (I964) is a montage of mushroom clouds presented for our grimly ironic (iconic?) and satiric delectation. Annihilation as ersatz-melodrama is completed as Vera Lynn sings "We'll Meet Again” (I939) when it is pretty clear that the poor sods under those stunning mushrooms will never meet anyone again.

RB: Siegfried Kracauer, Benjamin's friend and colleague at the Frankfurt School, wrote an entire book on German film entitled From Caligari to Hitler, a book in which Riefenstahl figures briefly but significantly. Kracauer, Benjamin and Adorno were all fascinated by the new art of cinema, visited the UFA studios and discussed movies among themselves. Whether or not Benjamin saw Triumph of the Will after leaving Germany, he was certainly aware of Riefenstahl and what she represented.

Having said that, I think the stark summons that concludes "Mechanical Reproduction"-aesthetics or politics-poses a false choice. Any genuine aesthetic response demands that we both feel and understand-indeed, as Kant argues in "Analytic of the Beautiful," that we integrate these faculties-and that means that the serious critic never abandons reason or analysis. We can admire Riefenstahl's artistry and despise her politics, just as we can delight in the deftness with which Homer narrates Odysseus' scar, without losing sight of the violence that occasioned it.

The famous ending to Dr. Strangelove both aestheticizes politics (those mushroom clouds are lovely) and politicizes aesthetics (the irony of the Vera Lynn song is devastating). And Kubrick's ending, in its own way, perfectly illustrates the parable that gives our dialogue its title. Those hungry birds only experience Zeuxis' painting when it smacks them in the face. Genuine art breaks down, breaks apart, estranges habitual perception, thereby enabling us to see anew. The grape produced by techne both is and is not a grape. And it is in that strangely beautiful space where is and is not come together that art performs all of its Oz-like wizardry. 